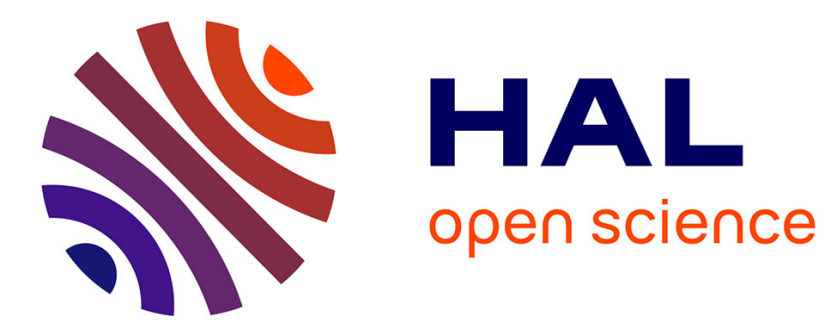

\title{
Late-Holocene NAO and oceanic forcing on high-altitude proglacial sedimentation (Lake Bramant, Western French Alps).
}

Hervé Guyard, Emmanuel Chapron, Guillaume St-Onge, Jacques Labrie

\section{- To cite this version:}

Hervé Guyard, Emmanuel Chapron, Guillaume St-Onge, Jacques Labrie. Late-Holocene NAO and oceanic forcing on high-altitude proglacial sedimentation (Lake Bramant, Western French Alps).. The Holocene, 2013, 23 (8), pp.1163-1172. 10.1177/0959683613483616 . insu-00905948

\section{HAL Id: insu-00905948}

\section{https://hal-insu.archives-ouvertes.fr/insu-00905948}

Submitted on 5 Jan 2021

HAL is a multi-disciplinary open access archive for the deposit and dissemination of scientific research documents, whether they are published or not. The documents may come from teaching and research institutions in France or abroad, or from public or private research centers.
L'archive ouverte pluridisciplinaire HAL, est destinée au dépôt et à la diffusion de documents scientifiques de niveau recherche, publiés ou non, émanant des établissements d'enseignement et de recherche français ou étrangers, des laboratoires publics ou privés. 


\title{
Late-Holocene NAO and oceanic forcing on high-altitude proglacial sedimentation (Lake Bramant, Western French Alps)
}

\author{
Hervé Guyard, ${ }^{1,2,3}$ Emmanuel Chapron, ${ }^{4}$ Guillaume St-Onge ${ }^{1,2}$ \\ and Jacques Labrie ${ }^{1,2}$
}

\begin{abstract}
Comparison of glacially derived clastic inputs in high altitude proglacial lake Bramant (Western French Alps) with measured North Atlantic Oscillation winter $\left(\mathrm{NAO}_{\mathrm{w}}\right)$ index reveals an inverse correlation between AD 1884 and 1968 at the pluridecadal timescale (20-25 years). This reflects periodical variations in snow accumulation over Lake Bramant catchment area partly influencing the glacier mass balance in the watershed. Further comparisons with reconstructed $\mathrm{NAO}_{\mathrm{w}}$ index since $\mathrm{AD} 1500$ highlight spatial and temporal variations of the pluridecadal $\mathrm{NAO}_{\mathrm{w}}$ influence on this alpine climate, especially at the end of the 'Little Ice Age'. In addition, wavelet analysis of continuous proxies of clastic sedimentation over the last 4I50 years indicates significant pluridecadal variability at frequencies compatible with the NAO (30 years), while periods centered at 60-70 years could also be linked to the North Atlantic Ocean-atmosphere internal variability (Atlantic Multidecadal Oscillation (AMO)). The influence of the North Atlantic deep water production on the regional alpine climate is also suggested by a significant $550 \mathrm{yr}$ cycle of clastic inputs since $2800 \mathrm{cal}$. BP. Coupling between the North Atlantic Ocean and the atmosphere seems therefore to play a fundamental role on glacier mass balance and climate during the late Holocene in the western Alps.
\end{abstract}

\section{Keywords}

AMO, ITRAX, late Holocene, NAO, proglacial lake, wavelet, Western French Alps

\section{Introduction}

The North Atlantic area is often recognized to have an important impact on the European climate. A large part of the winter atmospheric circulation variability in the North Atlantic region is associated with the North Atlantic Oscillation (NAO) (Hurrell, 1995) which is coupled to the North Atlantic sea surface temperature (SST) through latent heat fluxes (Rodwell et al., 1999). The NAO influences the underlying ocean and the surrounding continent. This major climate oscillation is described with an index defined as the difference between the standardized winter sea level pressure (SLP) at the Azores (High) and Iceland (Low) (Appenzeller et al., 1998; Hurrell, 1995). The SLP difference drives surface winds and winter storms from west to east across the North Atlantic and fluctuates at various timescales (e.g. Appenzeller et al., 1998; Cook et al., 1998; Hurrell and van Loon, 1997). During positive NAO phases (enhanced Azores High and enhanced Iceland Low, $\mathrm{NAO}+$ ), westerly flow is enhanced and moves relatively warm and moist maritime air over much of northwestern Europe while enhanced northerly winds over Greenland and northeastern Canada result in a drop in temperature over the northwestern Atlantic (Hurrell 1995). Opposite patterns of temperature and precipitation are typically observed in western Europe during negative phases of the NAO (reduced Azores High and reduced Iceland Low, NAO--) and enhanced winter precipitations in the NW Alps (Beniston, 1997; Chapron et al. 2002).

High altitude alpine environments are particularly sensitive to climate changes. Several studies have already shown that European alpine glacier mass balance is influenced by $\mathrm{NAO}_{w}$ phases (e.g. Reichert et al., 2001; Six et al., 2001). Proglacial lacustrine sediments are often used to reconstruct paleoclimates and paleoenvironments since glacier fluctuations, directly linked to winter precipitation and summer temperature, may be recorded in detrital sedimentary sequence accumulated in the basin (e.g. Chapron et al., 2007; Dahl et al., 2003; Guyard et al., 2007a; Neemann and Niessen, 1994; Nesje, 2009). As bedrock erosion rate increases with glacier size and thickness, fluctuations in the amount of silt- and clay-sized mineral fraction provide a reliable record of glacier activity. Particularly, time series analysis methods of continuous high-resolution sedimentary records are useful tools to decipher decadal to centennial climatic oscillations and to identify mechanisms and relationships between different components of the climate system (Chapman and Shackleton, 2000; Debret et al., 2009; Wanner et al., 2011).

This paper describes clastic supply fluctuations in relation to glacial activity from finely laminated sediments retrieved in high altitude proglacial Lake Bramant (Grandes Rousses Massif, Western French Alps; Figure 1). We present detrital input periodicities and their temporal evolution using continuous wavelet analysis

\footnotetext{
'Institut des sciences de la mer de Rimouski (ISMER), Université du Québec à Rimouski, Canada 2GEOTOP Research Center, Canada

${ }^{3}$ Laboratoire d'Océanologie et de Géosciences - UMR CNRS 8187; ULCO, France

${ }^{4}$ ISTO - UMR CNRS 7327; Université Orléans; BRGM, France
}

Received I8 May 2012; revised mansucript accepted I9 February 2013

\section{Corresponding author:}

Hervé Guyard, Laboratoire d'Océanologie et de Géosciences, - UMR CNRS 8187, 28 Avenue Foch, BP 80, 62930 Wimereux, France. Email: Herve.Guyard@univ-littoral.fr 

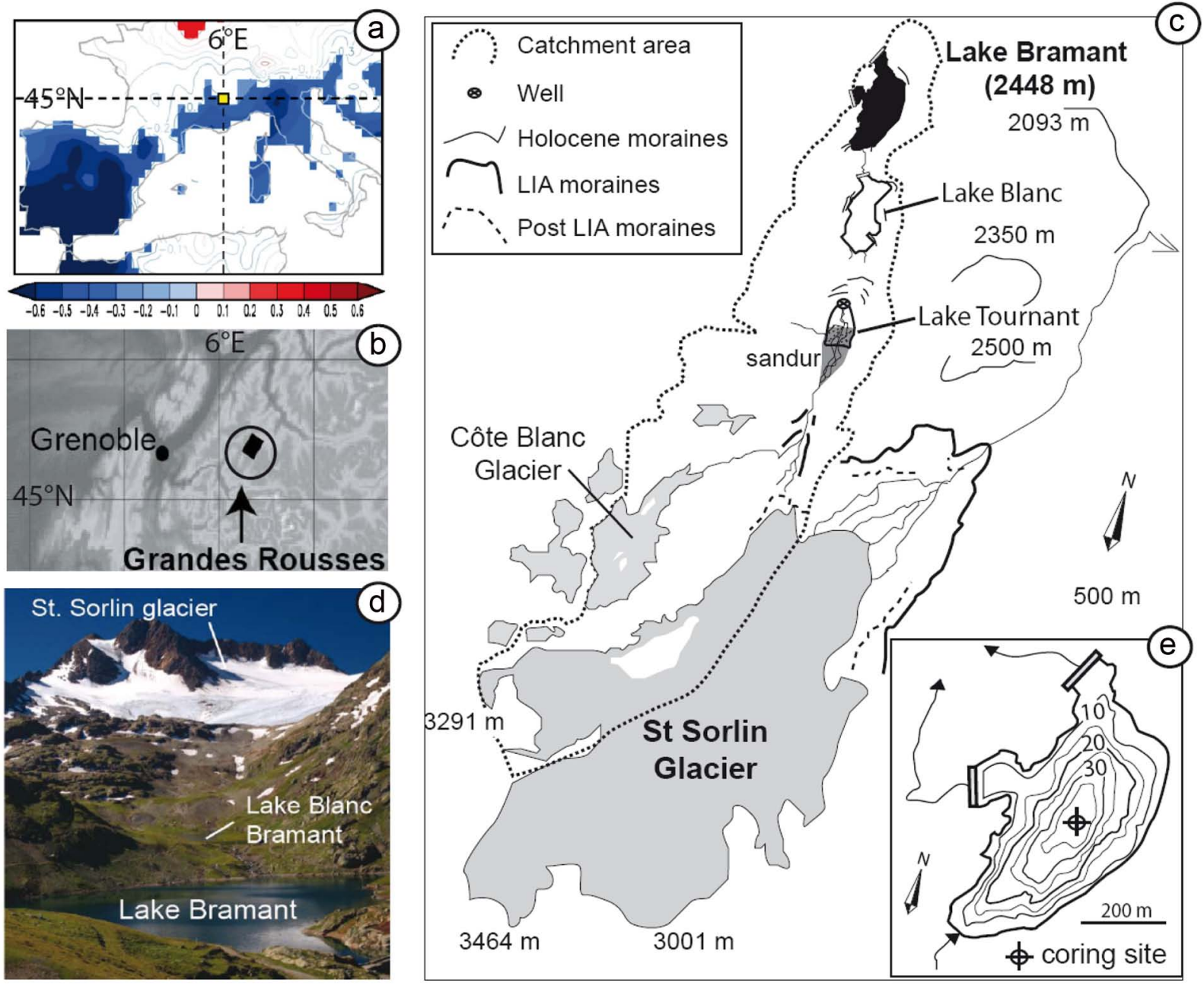

Figure I. (a) Location of the study area in Western Europe and spatial Spearman correlation between the NAO atmospheric teleconnection pattern (defined by Barnston and Livezey, 1987) and winter precipitations (AD 195I-2006) in the Mediterranean (modified from Roberts et al., 20I2). The shaded areas are significant at the $95 \%$ level $\left(-0.2\right.$ to -0.4 at the study area located near $\left.45^{\circ} \mathrm{N} / 6^{\circ} \mathrm{E}\right)$. (b) General location of the Grandes Rousses massif in the western French Alps and (c) details of Lake Bramant catchment area (thick dotted line) in the northern part of the massif consisting of a chain of proglacial lakes draining the Côte Blanc glacier and a diffluence of the St. Sorlin glacier in the Bramant valley. Several generations of moraines are recognized downstream of the St. Sorlin glacier. (d) Photograph (by Michel Caplain) illustrating the St. Sorlin glacier and the proglacial lakes Blanc and Bramant. (e) Lake Bramant bathymetry and location of the coring site in the deep basin of the lake.

and global spectrum in order to examine large-scale climatic mechanisms influencing the glacial dynamic and resulting proglacial sedimentation over the last $4150 \mathrm{cal}$. BP.

\section{Setting}

The large majority (81\%) of glaciers in the Alps are small $(<0.5$ $\mathrm{km}^{2}$ ) (Zemp, 2006). The St. Sorlin glacier $\left(3 \mathrm{~km}^{2}\right)$ located on the northern part of the Grandes Rousses Massif $\left(45^{\circ} 7{ }^{\prime} \mathrm{N}, 6^{\circ} 6^{\prime} \mathrm{E}\right)$ between $2650 \mathrm{~m}$ a.s.1. and $3400 \mathrm{~m}$ a.s.1. (Figure 1) is sensitive to climate changes (Vincent, 2002) and generally considered as representative for the NW alpine region (Six et al., 2001; Vincent, 2002). In the glacial Bramant valley, Lake Bramant (2448 m a.s.1.) is the third and lowermost lake of a chain of high altitude small proglacial lakes and drains the Côte Blanc glacier and only the western part of the St. Sorlin glacier, because of a glacial diffluence on a bedrock knob (Figure 1). Glacial meltwaters are naturally filtered by the upper proglacial lakes (Lake Tournant and Lake Blanc), which successively retain the coarser particles. Today, the outlet of Lake Blanc constitutes the main tributary of Lake Bramant. As such, clastic inputs originating from glacial melting are mainly characterized by fine detritic elements ranging from fine sand to fine silts (Guyard et al., 2007a).
Sediment cores retrieved from the Lake Bramant deep basin contain two dark and organic-rich intervals reflecting lower lakelevel periods from 4150 to $3600 \mathrm{cal}$. BP and from 3300 to 2850 cal. BP resulting from reduced glacier activity in the drainage basin (Guyard et al., 2007a; Figures 2 and 3). The onset of lighter clastic proglacial sediments and higher lake level between 3600$3300 \mathrm{cal}$. BP and since $2850 \mathrm{cal}$. BP indicate periods of higher glacier activity associated with an upstream diffluence that acts as an on-off switch of glacial meltwater supply into the Bramant Valley (Chapron et al., 2008; Guyard et al., 2007a). Sediments are finely laminated throughout the sequence (Figure 2). Coarser and darker laminations are characterized by lower fine detritic element contents and higher organic matter contents. The thicknesses of these darker laminations are variable.

\section{Materials and methods}

\section{Sedimentological analyses and composite sequences}

The piston (BRA03) and gravity (BRA03-1) cores were run through an ITRAX core Scanner (Mo tube) at INRS-ETE (Quebec city) to detect relative variations of geochemical elements from $\mathrm{Al}$ to U (e.g. Croudace et al., 2006; Guyard et al., 2011) in order to 


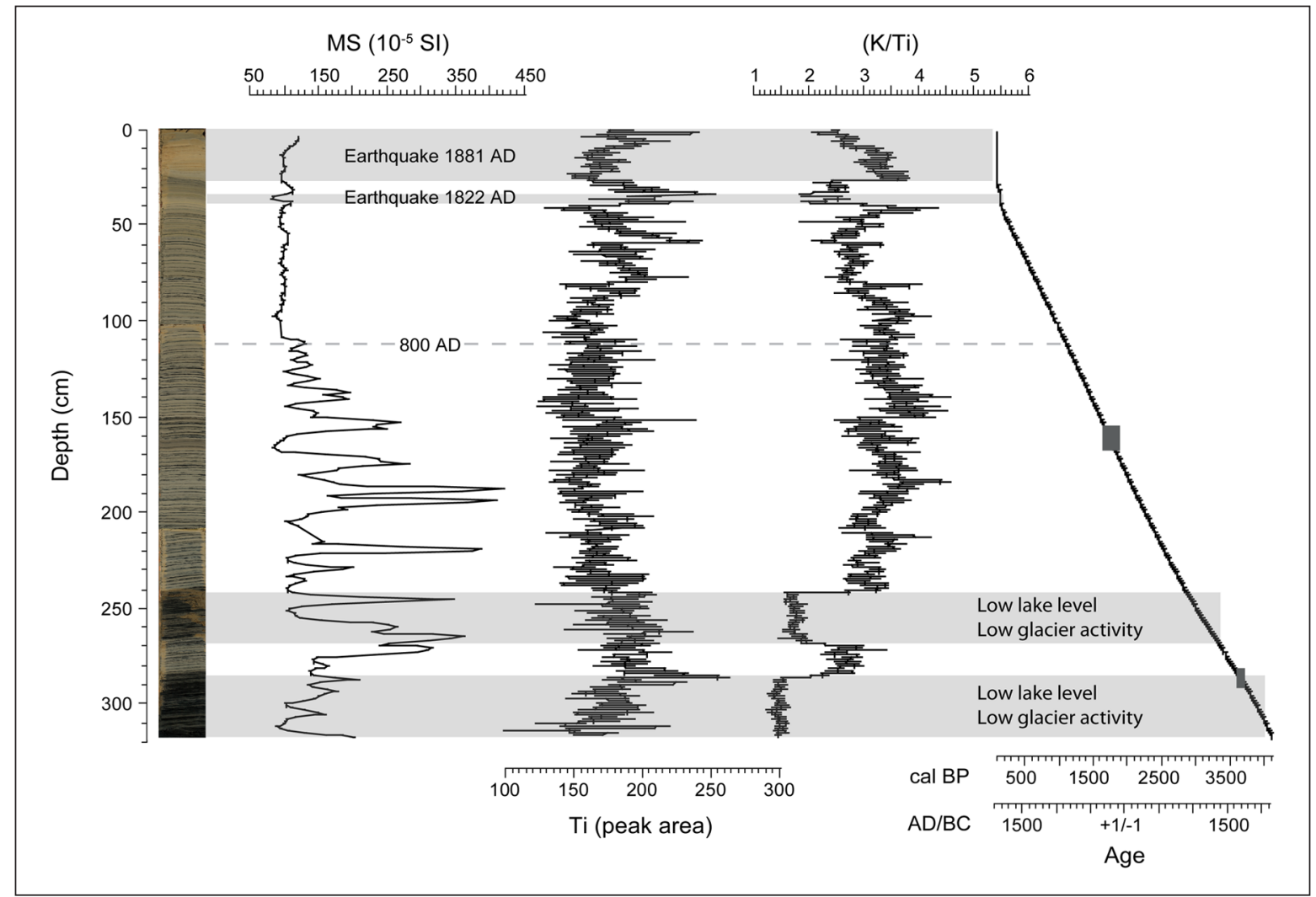

Figure 2. General simplified lithostratigraphy of the core BRA03 and clastic fluctuations (Ti and K/Ti) since $4 I 50$ cal. BP. MS: volumetric magnetic susceptibility. The age-depth relationship is detailed in Guyard et al. (2007a). The dark grey highlights periods of local or regional mining activity. The thin dotted line illustrates a major sedimentological change at AD 800 (see text for details).

investigate fluctuations of glacially derived clastic inputs. Analyses were performed at a downcore resolution of $300 \mu \mathrm{m}$ for BRA03-1 (corresponding to about 12 data points per year on average; irradiation during $10 \mathrm{~s}$ ) and $100 \mu \mathrm{m}$ for BRA03 (corresponding to about 6 data points per year; irradiation during 1s). We used the ratio $\mathrm{K} / \mathrm{Ti}$ as a proxy for glacial flour since $\mathrm{K}$ is generally associated with fine detrital clay (Croudace et al., 2006) and Ti fluctuations for global detritic inputs (i.e. not necessarily glacially derived). Volumetric magnetic susceptibility was measured at 1 $\mathrm{cm}$ intervals on u-channel samples at the University of Florida.

The age-depth model was previously established and is based on the combination of ${ }^{137} \mathrm{Cs},{ }^{241} \mathrm{Am}$ and radiocarbon dating, varve counting, the recognition of historical natural events and on the regional or local mining activity records (Carozza et al., 2010; Chapron et al., 2008; Guyard et al., 2007a). Cores BRA03-1 and BRA03 comprise an AD 1884-1968 and a $\sim 4150-100$ cal. BP sedimentary record, respectively. The composite sequence for short core BRA03-1 (Figure 4) was constructed after removing the top of the slump associated with the nearby AD 1881 Allemond earthquake and 2cm thick flood deposits dated at AD 1904-1905 and 1908-1910, likely related to major glacier retreat (Guyard et al., 2007a, 2007b). In a similar manner, the composite sequence of BRA03 was established after removing the base of the slump associated with the 1881 Allemond earthquake and the turbidite triggered by the $\mathrm{AD} 1822$ Chautagne earthquake (Figure 2; Guyard et al., 2007a, 2007b). Both cores were retrieved at the same coring site (Figure 1) and the spectral signal obtained as discussed below can therefore be compared.

\section{Wavelet analysis}

The clastic sedimentary records were investigated using the continuous wavelet transformation, which is a useful method to analyze complex non-stationary time series (Torrence and Compo,
1998; Witt and Schumann, 2005). In this study, the Morlet wavelet (a Gaussian-modulated sine wave) was used for the continuous wavelet transform. The region of the wavelet spectrum in which edge effects becomes significant is known as the cone of influence (COI), defined as the e-folding time for the autocorrelation of wavelet power at each scale. The wavelet power spectral density was calculated for each parameter following Torrence and Compo (1998) and the interval of $95 \%$ confidence is marked by black thin contours. We used red noise background spectrum (increasing power with decreasing frequency) to determine the significant levels of the global wavelet power spectrum. Raw data of clastic fluctuations (reflected by $\mathrm{K} / \mathrm{Ti}$ and $\mathrm{Ti}$ variations) was first transformed in temporal data and then resampled every year by linear interpolation. A low pass filter was applied to the annual data to attenuate the very high frequencies before performing statistical analyses on lower frequencies (e.g. Boucher et al., 2011; Chapron et al., 2002; Six et al., 2001). The power of these lower frequencies already present in the raw data was thus increased by the filtering process owing to the attenuation of the high frequencies (e.g. noise). For short timescales (e.g. the instrumental period), a low pass filter (5- to 11-year running mean) was applied to reduce the 'noise' of small-scale and transient meteorological phenomena not related to large-scale climate variability. For longer timescales, centennial cycles of clastic fluctuations were determined after low pass filtering (100-year running mean) in order to study their long-term variations. To focus on pluridecadal periodicities, we removed the long-term variation by subtracting the 100-years smoothed time series from the annual data following Chapron et al. (2002). Once again, a low pass filter (5- to 11-year running mean) was then applied to attenuate the influence of the high frequencies on the signal. All data were normalized to the standard deviation.

Cross wavelet transforms (Grinsted et al., 2004) were also constructed to examine the variability of the relationship between 


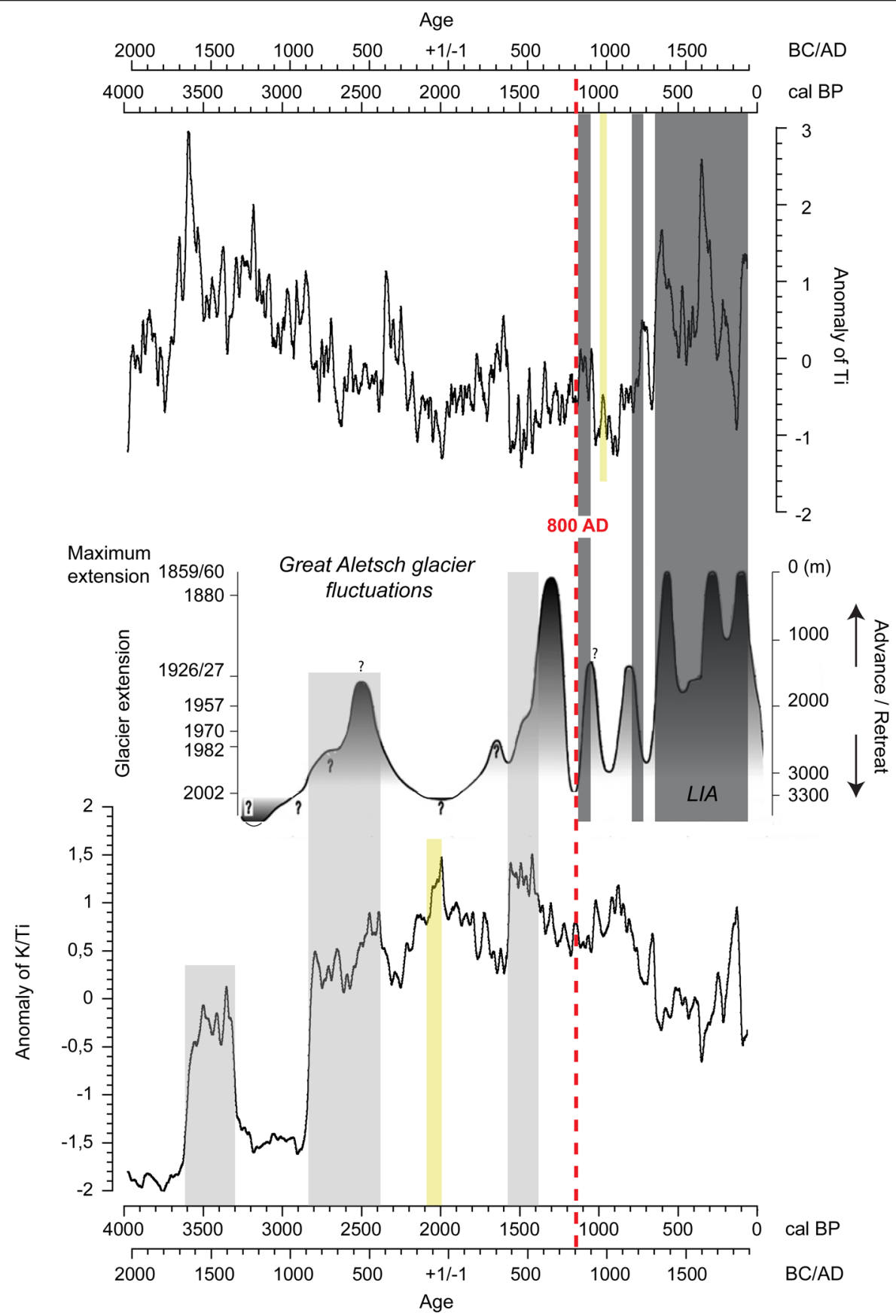

Figure 3. Comparison between proglacial Lake Bramant clastic sedimentation and the Great Aletsch glacier fluctuations. Modified after Holzhauser et al. (2005). Light and dark grey intervals highlight the glacial advance periods correlated with higher $\mathrm{K} / \mathrm{Ti}$ and Ti inputs, respectively. The red dashed line marks the sedimentation change C. AD 800 . The glacial activity fluctuations from AD 800 are reflected by Ti variations. The yellow zones illustrate higher clastic inputs in Lake Bramant that are correlated with clastic fluctuations in Lake Le Bourget record (Debret et al., 2010). LIA: 'Little Ice Age'. K/Ti and Ti anomalies were smoothed by a 30-year running mean (colour figure available online).

the NAO and clastic fluctuations since AD 1500. The analysis of the covariance of the two time series and the $95 \%$ confidence level follow the work of Torrence and Compo (1998). The Morlet wavelet cross-spectra permit to depict the features common to the climatic indices and NAO index and to highlight temporal variations in their relationship. If the coherence between two series is high, the arrows in the coherence spectrum (Figures 4 and 5) show the phase between the time series: arrows at horizontal right (left) indicate that both time series are in phase (anti-phase) and imply a linear relationship. As the influence of the NAO on glacier fluctuations is most pronounced during winter (e.g. Nesje et al., 2000), only the winter NAO index $\left(\mathrm{NAO}_{\mathrm{w}}\right)$ (December-February) is considered here for comparison. Furthermore, since the
$\mathrm{NAO}$ and climate indices as well as the glacier fluctuations are highly variable on the annual timescale (e.g. Six et al., 2001), the records were smoothed (5- to 11-year running mean) to remove the annual variability.

\section{Results and discussion}

\section{Glacier fluctuations}

The increase of the ratio K/Ti observed between 1650 and 1350 $\mathrm{BC}$ (Figure 3) reflects higher erosion resulting from stronger glacier activity in the catchment. This is in agreement with a wetter and colder period documented by a high lake-level period between 1600 and 1200 BC in west-central Europe (e.g. Holzhauser et al., 

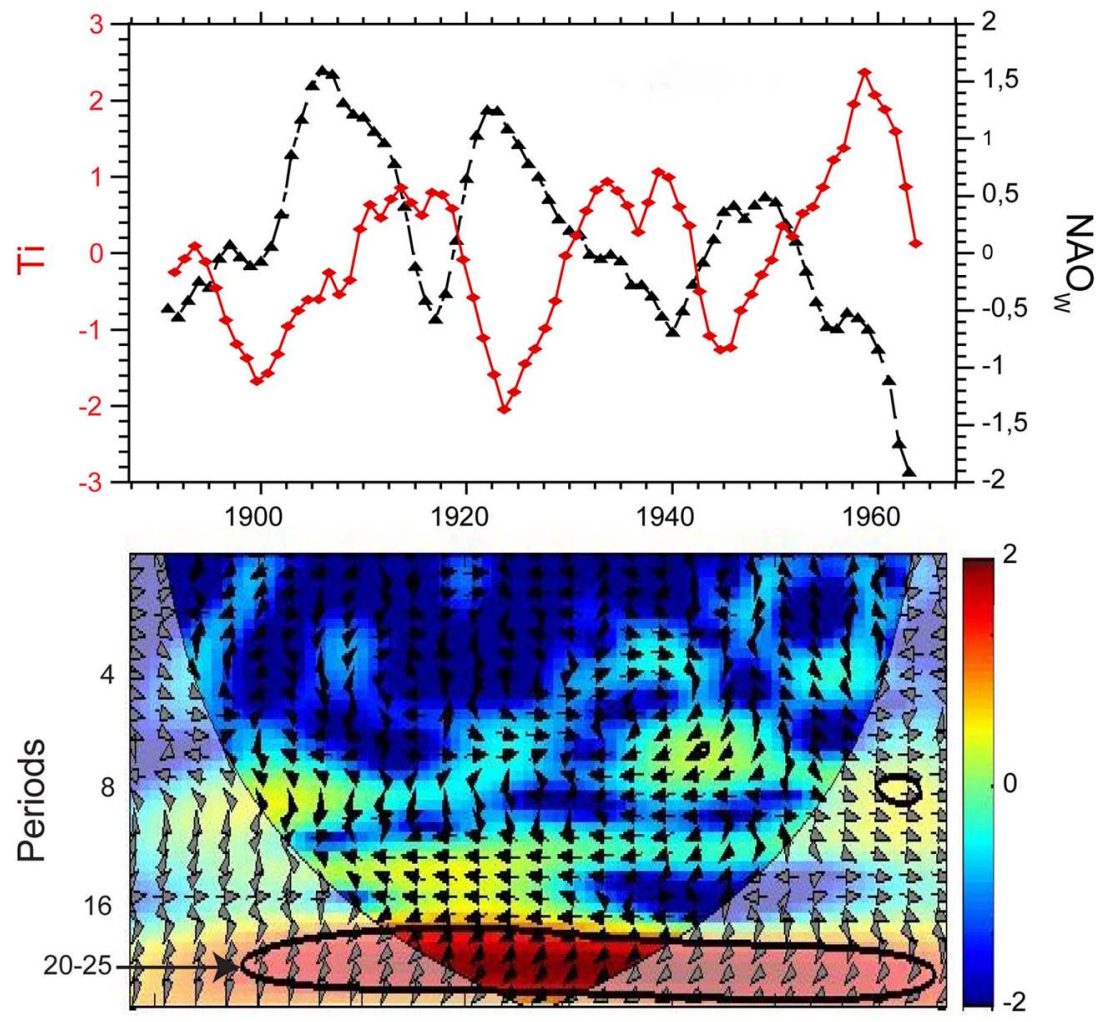

Figure 4. NAO winter index (Hurrell, 1995) and Ti fluctuations between AD I888 and 1965. Both curves are normalized and smoothed by a 5 -year running mean to reveal a common signal between both variables by reducing the annual to pluriannual 'noise'. The lower panel illustrates the results of cross wavelet analysis results which reveal a significant anti-phase relationship between both time series on multidecadal timescales (20-25 years) (sampling period: I year). The lighter area denotes the $\mathrm{COI}$ and black contours represent the $95 \%$ confidence level based on a red-noise background. When the coherence between the two series is high, arrows at horizontal left (right) in the coherence spectrum indicate that both time series are in anti-phase (phase) (colour figure available online).

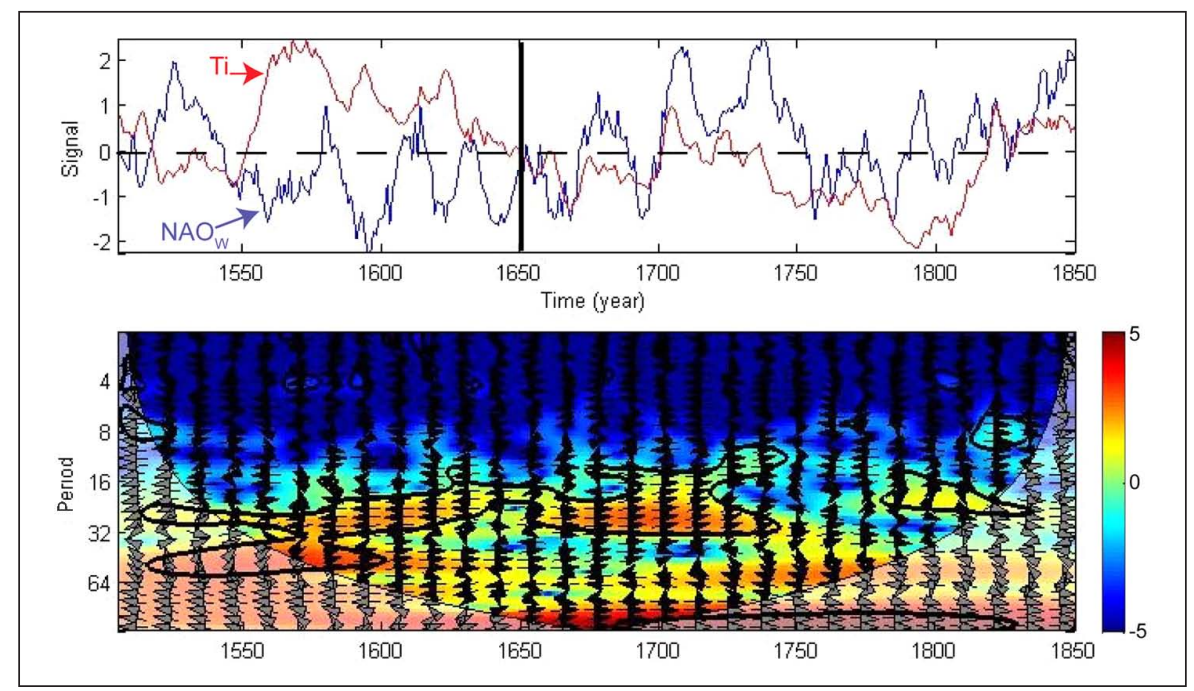

Figure 5. Reconstructed NAO winter index (DJF) (Luterbacher et al., 2002) and Ti fluctuations between AD I500 and I850. Both curves are normalized and smoothed by a I I-year running mean. The lower panel illustrates the results of cross wavelet analysis which reveal a significant and variable relationship between both time series on multidecadal timescales (20-25 years) (sampling period: I year). The lighter area denotes the COI and black contours represent the $95 \%$ confidence level based on a red-noise background. When the coherence between the two series is high, the arrows at horizontal left (right) in the coherence spectrum indicate that both time series are in anti-phase (phase) (colour figure available online).

2005). The increase of the $\mathrm{K} / \mathrm{Ti}$ ratio observed between $900-450$ $\mathrm{BC}$ and $\mathrm{AD}$ 350-550 (Figure 3) is also interpreted as an increase in glacial activity and glacial erosion. These two periods correspond to late-Holocene cold events described in Wanner et al. (2011) and are relatively synchronous to glacial advances in the Swiss
Alps (Holzhauser et al., 2005) (Figure 3). Indeed, probably because of its small size, St. Sorlin glacier may respond to climatic forcing slightly before more continental European glaciers, such as the much larger Aletsch glacier (Deroin and Condom, 2007; Holzhauser et al., 2005). The increase of clastic inputs 
observed around BC 150 is also consistent with clastic fluctuations in the Lake Le Bourget record, indicating enhanced Rhone River flooding activity in large alpine valleys (Chapron et al., 2005; Debret et al., 2010).

From $\sim$ AD 800 , a major lithological change in the sedimentation is reflected by slightly darker sediments, a drop in magnetic susceptibility values and a decreasing trend of $\mathrm{K} / \mathrm{Ti}$ content (Figures 2 and 3), as well as by a rise of measured gamma density values and by less sorted and slightly coarser silty sediments (Guyard et al., 2007a). This mineralogical and/or grain size change is probably associated with a sedimentary source variation and could result from sedimentary filling of the uppermost proglacial and shallow Lake Tournant (Figure 1) following the regional alpine glacier advance (e.g. Holzhauser et al., 2005) and the associated late-Holocene cold event (Wanner et al., 2011). This is consistent with a similar change in the sedimentary infill observed in Lake Tournant at the end of the LIA (Shaw et al., 1958). As a result, the glacial activity fluctuations from AD 800 become better recorded in Lake Bramant by Ti variations which probably reflect coarser grain size and indicate glacial advance between $\mathrm{AD} 800$ and 900, around $\mathrm{AD} 1200$ and since $\mathrm{AD} 1350$ (Figure 3). These periods are synchronous with glacial advances in the Swiss Alps (Holzhauser et al., 2005; Figure 3), with higher lake level periods in Western Europe (Magny, 2004) and with clastic fluctuations in Lake Le Bourget record (Chapron et al., 2002, 2005; Debret et al., 2010).

The LIA was dated south of the Massif between AD 1350 and 1880 and resulted in the lowering of glacial equilibrium line altitude (ELA) in the western French Alps and intense flooding in the alpine valleys (Chapron et al., 2007; Vincent et al., 2005). Maximum Ti inputs around AD 1350, between AD 1580 and 1620 and $A D$ 1820-1850 (Figure 3) are consistent with LIA maximum glacial expansion in the Alps (e.g. Nussbaumer et al., 2007). Significant glacial fluctuations also occurred during the 18th century and are indicated by darker sediments with lower Ti contents, suggesting an elevation of the ELA in the drainage basin (reduced glacier activity). This period is also reflected by more organic sediments in proglacial Lake Blanc Huez, located in the southern part of the Massif (Chapron et al., 2007).

\section{Impact of the NAO on Lake Bramant recent sedimentation}

Direct correlation between the $\mathrm{NAO}_{\mathrm{w}}$ index measured since 1880 (Hurrell, 1995) and glacial clastic inputs over Lake Bramant watershed is weak, reflecting the relatively low relationship between alpine glacier mass balance and NAO fluctuations at the annual timescale (see also Imhof et al., 2012; Marzeion and Nesje, 2012; Six et al., 2001). Nevertheless, by reducing this annual 'noise' (running mean), the comparison of the time series revealed an anticorrelation between the glacial meltwater supply (reflected by Ti fluctuations) and the measured $\mathrm{NAO}_{\mathrm{w}}$ index at decadal timescales (Figure 4). This inverse relationship thus suggests oscillations in snow precipitation and accumulation during late autumn and winter over Lake Bramant catchment area influencing the St. Sorlin and Côte Blanc glacier mass balances and erosive processes over the catchment at decadal timescales (enhanced precipitation and snow accumulation during NAO- phases). In addition, the cross wavelet analysis confirms a relatively strong anti-phase relationship between both time series at the multidecadal timescales (20-25 years), while multiannual variability appears to be less correlated to the NAO (Figure 4). This reflects the complexity of glacial systems and dynamics. Moreover, the 20-25 year periodicity is consistent with fluctuations of the $\mathrm{NAO}_{\mathrm{w}}$ index at decadal timescales (e.g. Cook et al., 1998; Rogers, 1984).

$\mathrm{NAO}+$ phases are generally correlated with anomalously low precipitation and higher than average temperatures during the winter in southern and much of Central Europe, including the Alps (Beniston and Jungo, 2002; Wanner et al., 1997), while heavier-than-average precipitations are observed over northern Europe and Scandinavia (Hurrell and van Loon, 1997; Selten et al., 1999). These conditions result in reduced winter accumulation and lower mass balance (ELA elevation) of European alpine glaciers and thus, after a certain delay, to their retreat (Nesje et al., 2000; Reichert et al., 2001; Six et al., 2001). Six et al. (2001) found that the annual NAO index explains at best $36 \%$ of the St. Sorlin annual mass balance variance $(r=-0.6)$ while Reichert et al. (2001) found an inverse relationship between decadal variations in the $\mathrm{NAO}_{\mathrm{w}}$ index and the Rhone Glacier (Switzerland) mass balance $(r=-0.64)$ using a modeling approach.

On the other hand, the NAO influence on mass balance of Scandinavian glaciers is positive and more pronounced than in the alpine region (Imhof et al., 2012; Six et al., 2001), probably because the dynamic of Scandinavian maritime glaciers are mostly driven by winter precipitations originating from the North Atlantic area, while the alpine glaciers are more sensitive to summer temperature (which is less influenced by NAO) (Reichert et al., 2001; Steiner et al., 2008). During the 20th century, glacier fluctuations observed in the alpine region are essentially controlled by mean summer temperature (Vincent, 2002). Furthermore, as the Alps are situated in the transition zone between northern Europe and southern Europe, the NAO influence on European alpine climate is more complex and sometimes equivocal (Casty et al., 2005; Scherrer et al., 2004).

\section{Impact of the NAO during the LIA}

Further comparison between clastic inputs and reconstructed $\mathrm{NAO}_{\mathrm{w}}$ index (Luterbacher et al., 2002) highlights a negative correlation between $\mathrm{AD} 1500$ and 1650 similar to that during the 20th century followed by a positive correlation between AD 1650 and 1850 . This could indicate that the multidecadal NAO influence (20-25 years) was not constant during the LIA, as also shown by the cross wavelet results (Figure 5). These results may thus reflect the non-stationarity and non-linearity characteristics of large-scale phenomena on alpine glacier mass balance and climate.

The glacier variations in the European alpine area are asynchronous with the glacial fluctuations in Scandinavia partly because of the multidecadal trends in the north-south dipole NAO pattern (e.g. Imhof et al., 2012; Nesje and Dahl, 2003). The negative and weaker correlation (compared with Scandinavian glaciers) between $\mathrm{NAO}_{\mathrm{w}}$ index and Ti inputs in Lake Bramant probably indicate that decreasing temperature may be the dominating factor responsible for the LIA glacier advances in the Grandes Rousses massif until AD 1650. This is in agreement with summer temperature reconstruction over the Alps (Büntgen et al., 2006 ) indicating a prolonged cooling during AD 1350-1700. The following positive correlation observed between $\mathrm{AD} 1700$ and 1850 could reflect hemispheric-scale atmospheric circulation reorganizations during the last part of the LIA and a southern shift of westerlies, since an increase of winter precipitation would be responsible for glacier advance in western Scandinavian in the early 18th century (Nesje and Dahl, 2003; Nesje et al., 2008). A higher influence of winter precipitation during the last LIA phase of alpine glacier advance was also proposed by Vincent et al. (2005), who demonstrated an increase of at least $25 \%$ of winter precipitation between $\mathrm{AD} 1760$ and 1850. Nevertheless, as the analysis of regional reconstructed precipitation variability over the last 500 years reveals major non-stationarities with large-scale circulation patterns (e.g. Pauling et al., 2006), other modes of atmospheric circulation may thus have controlled Alpine climate variability through the recent past, as proposed by Casty et al. (2005). 


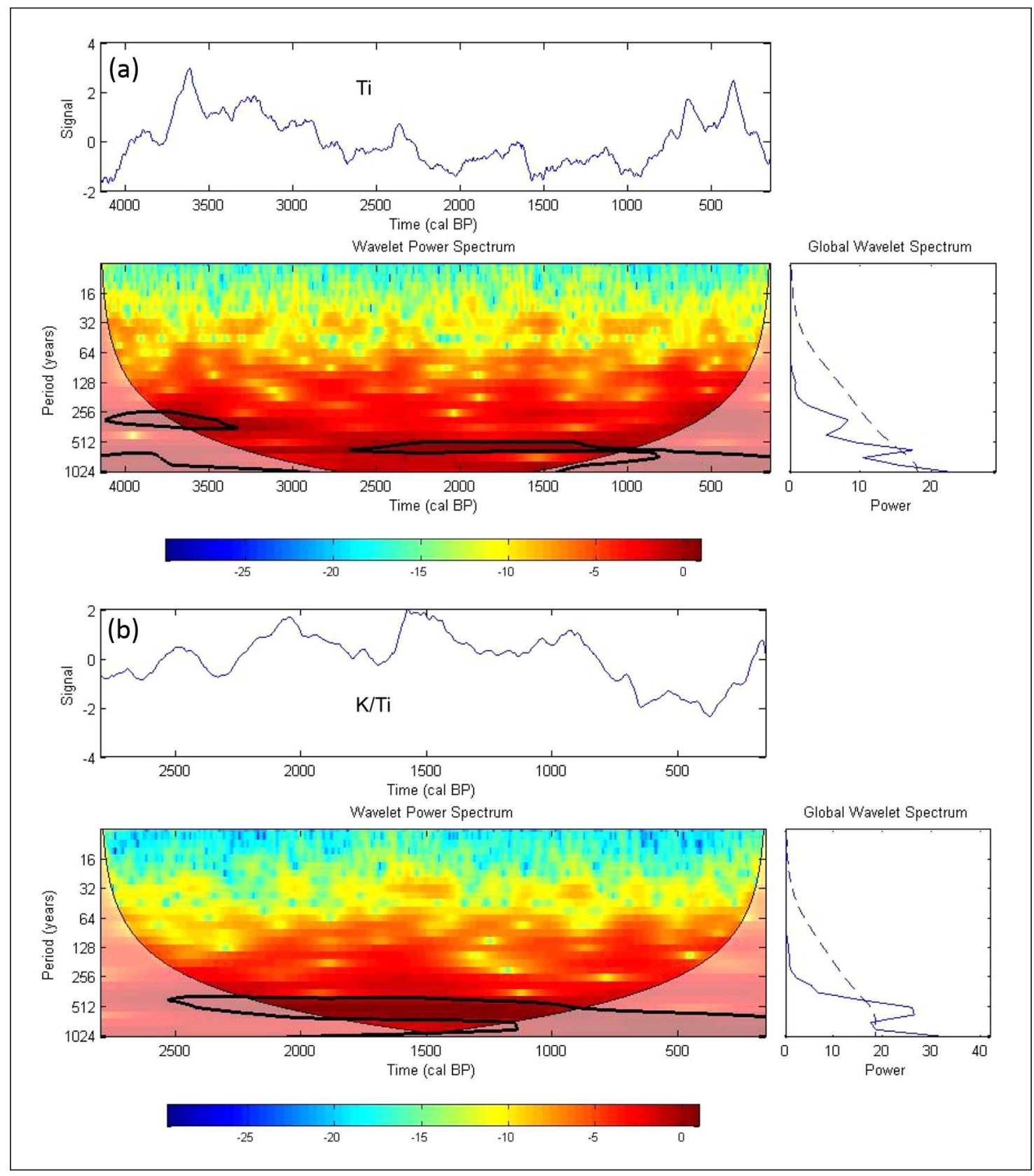

Figure 6. Low frequency variability of clastic supply. (a) Ti fluctuations between 4100 and I00 cal. BP and (b) K/Ti between 2850 and I00 cal. BP. Both time series are smoothed by a 100-year running mean. Sampling period: 4 years. The lighter area denotes the COI and black contours represent the $95 \%$ confidence level based on a red-noise background (colour figure available online).

\section{North Atlantic oceanic forcing}

On longer timescales, clastic supply fluctuations depict significant periodicities centered at 550-600 years since the last significative St. Sorlin glacier advance c. 2800 cal. BP (e.g. Chapron et al., 2008) (Figure 6). This low-frequency fluctuation was associated with changes in North Atlantic deep water (NADW) circulation (Chapman and Shackleton, 2000) which are also coherent with fluctuations in atmospheric conditions over Greenland (Stuiver et al., 1995). Our results thus imply significant impact of late-Holocene climate variability over the North Atlantic region on alpine climate and glacier mass balance at the centennial timescale.

Furthermore, clastic fluctuations depict significant pluridecadal periodicities centered at 30 years and especially at 60-70 years (Figure 7). These pluridecadal oscillations were observed throughout the sequence within Ti fluctuations, while they were not recorded during the two warmer periods occurring during the Bronze Age within $\mathrm{K} / \mathrm{Ti}$ (and K) fluctuations. They are consistent with typical periods of the NAO (Appenzeller et al., 1998; Cook et al., 1998; Hurrell and van Loon, 1997; Luterbacher et al., 1999) and in North Atlantic climate variability (Schlesinger and Ramankutty, 1994). We suggest that darker laminations observed throughout the record (Figure 2) are associated with extreme and/ or long NAO+ phases possibly forced by SST pluridecadal variability in the North Atlantic Ocean and result from associated warmer and drier conditions. Similarly, both organic intervals deposited during the Bronze Age may reflect prolonged NAO+ periods.

On decadal and longer timescales, the variation in the NAO could be forced by the North Atlantic SST variability (Kushnir, 1994; Rodwell et al., 1999) and there could possibly be a coherent but sporadic relationship between the amplitude and phase of the NAO and the SST (Higuchi et al., 1999). According to these authors, the amplitude and phase of the interdecadal component of the NAO are modulated by the North Atlantic SST at cycles of 30 and 60 years, respectively. The NAO may also influence the 


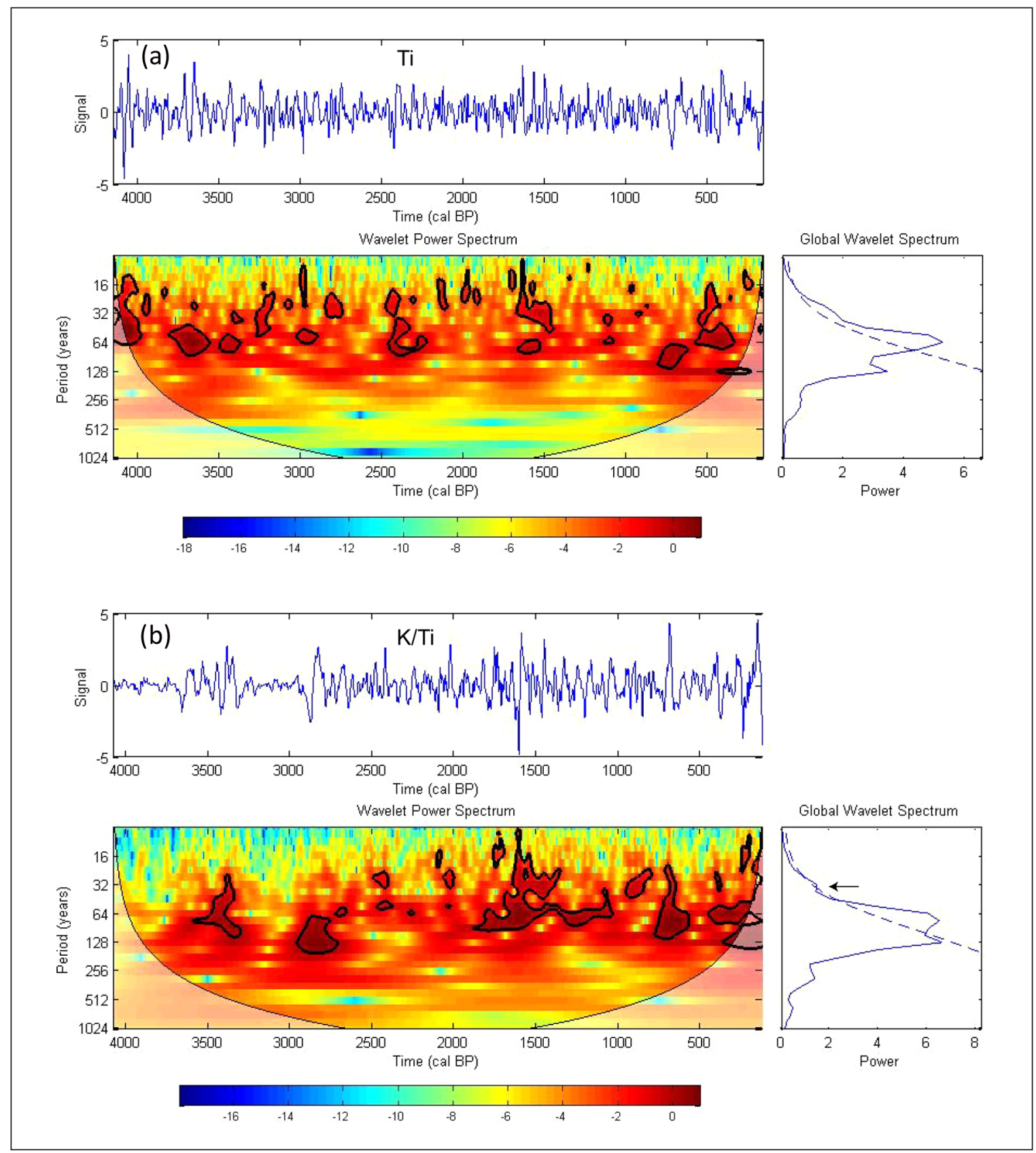

Figure 7. Pluridecadal variability of $\mathrm{Ti}(\mathrm{a})$ and $\mathrm{K} / \mathrm{Ti}$ (b) over the last 4100 years obtained by removing the long-term variations from the annual time series as in Chapron et al. (2002). Sampling period: 4 years. The lighter area denotes the COI and black contours represent the $95 \%$ confidence level based on a red-noise background (colour figure available online).

intensity variability of deep convection and thus of the meridional overturning circulation (MOC) (Curry et al., 1998; Dickson et al., 1996), which also exhibits variability at periods near 30 and 60 years in a coupled atmosphere/ocean general circulation model (Zhu and Jungklaus, 2008).

On the other hand, Schlesinger and Ramankutty (1994) identified in the global climate system a temperature oscillation of 65-70 years attributed to an internal oscillation of the ocean/ atmosphere system. Furthermore, Knudsen et al. (2011) showed that a persistent 55-70 years oscillation characterized the North Atlantic Ocean-atmosphere variability over the last 8000 years. The roughly 65-year oscillation of North Atlantic SSTs (Atlantic Multidecadal Oscillation, AMO; Kerr, 2000) is assumed to be related to multidecadal fluctuations of the thermohaline circulation (Delworth and Mann, 2000; Knight et al., 2005). This persistent natural oscillatory mode has been recognized to affect climate on surrounding continents because of changes in the intensity and direction of propagation of cyclones and anticyclones (e.g. Knight et al., 2006). In Europe, positive AMO is associated with positive near-surface air temperature anomalies. In addition, glacier mass balance in Switzerland has been recently significantly anticorrelated to the Atlantic Multidecadal Oscillation (AMO) index (Huss et al., 2010). This is consistent with the decadal fluctuations of the North Atlantic climate influencing European surface-temperature, precipitation and storminess through evaporation, precipitation and atmospheric-heating processes (Keenlyside et al., 2008; Rodwell et al., 1999). Furthermore, Sutton and Hodson (2005) provided evidence that 'basin-scale changes in the Atlantic Ocean, probably related to the thermohaline circulation, have been an important driver of multidecadal variations in the summertime climate of western Europe'. The oscillations of clastic supply recorded in proglacial Lake Bramant thus likely indicate that North Atlantic oceanic variability may influence glacier mass balance present in 
the watershed and regional climate through coupling with the atmosphere at various timescales.

\section{Conclusions}

The geographic location and the high altitude of the Grandes Rousses glaciers in the Western French Alps may explain their relatively high sensibility to the west-component atmospheric fluxes originating from the Atlantic Ocean, i.e. to depression regimes directly reflected by the NAO index. The glacial advances in the massif occurred generally slightly earlier than the much larger Swiss alpine glaciers, probably because of their small size which makes them more sensitive to climatic fluctuations. Clastic fluctuations exhibit enhanced pluridecadal periodicities that appear to be related to similar NAO variations. A NAO-like period in our data would be a consequence of variations in rainfall and snow accumulation during late autumn and winter over the watershed of proglacial Lake Bramant, which would partly influence glacier mass balance. The cycle centered at $60-70$ years could also be related to internal variability between the North Atlantic Ocean/atmosphere, possibly reflecting the Atlantic Multidecadal Oscillation. In addition, longer periods (550-600 years) observed in clastic fluctuations since 2800 cal. BP strongly suggest that other large-scale climatic phenomena such as variations in NADW production is leading to changes in temperature, precipitation and storminess in the alpine massif. The North Atlantic Ocean and climate variability seem therefore to play a major role on these high altitude alpine climate and glacier mass balance during the late Holocene.

\section{Acknowledgements}

The authors would like to thank Flavio Anselmetti (Bern University, Switzerland) for his contribution during the seismic and short coring survey in 2003 and to Bruno Axelard (Refuge de L'Etendard) for his support during the piston coring operations realized in collaboration with $\mathrm{O}$ Lie and the coring team from Bergen University (Norway). Jean- François Crémer is acknowledged for his helps in the laboratory. We also acknowledge Jürg Luterbacher (University of Giessen, Germany), Elena Xoplaki (Bern University) and Neil Roberts (Plymouth University, UK) for providing Figure 1(a). Thanks are also due to David Fortin (INRSETE, Canada) for discussions and to Pierre Francus (INRS-ETE) and Flavio Anselmetti (Bern University) for their detailed comments on an earlier draft of the manuscript. We also acknowledge Atle Nesje (Bergen University) for his editorial guidance and two anonymous reviewers for their constructive comments.

\section{Funding}

This study was supported by the French Mountain Institute, the Natural Sciences and Engineering Research Council of Canada (NSERC) and by the Canadian Foundation for Innovation (CFI).

\section{References}

Appenzeller C, Stocker TF and Anklin M (1998) North Atlantic Oscillation dynamics recorded in Greenland Ice cores. Science 282: 446-449.

Barnston AG and Livezey RE (1987) Classification, seasonality and persistence of low frequency atmospheric circulation patterns. Monthly Weather Review 115: 1083-1126.

Beniston M (1997) Variation of snow depth and accumulation in the Swiss Alps over the last 50 years: Links to changes in large-scale climatic forcing. Climatic Change 36: 281-300.

Beniston M and Jungo P (2002) Shifts in the distribution of pressure, temperature and moisture and changes in the typical weather patterns in the Alpine region in response to the behavior of the North Atlantic Oscillation. Theoretical and Applied Climatology 71: 29-42.

Boucher E, Guiot J and Chapron E (2011) A millennial multi-proxy reconstruction of summer PDSI for Southern South America. Climate of the Past 7: 957-974.
Büntgen U, Frank DC, Nievergelt D et al. (2006) Summer temperature variations in the European Alps, A.D. 755-2004. Journal of Climate 19: 5606-5623.

Carozza L, Chapron E, Simonneau A et al. (2010) Glacial fluctuations and exploitation of copper resources in high mountain during the late Neolithic and Bronze Age in the French Alps (2500-1500 BC). In: Anreiter P et al. (eds) Mining in European History and its Impact on Environment and Human Societies, Proceedings for the 1st Mining in European History. 12-15 November 2009, Innsbruck: Innsbruck University Press, pp. 81-90.

Casty C, Wanner H, Luterbacher J et al. (2005) Temperature and precipitation variability in the European Alps since 1500. International Journal of Climatology 25(14): 1855-1880.

Chapman MR and Shackleton N (2000) Evidence of 550-year and 1500-year cyclicities in North Atlantic circulation pattern during the Holocene. The Holocene 10(3): 287-291.

Chapron E, Arnaud F, Noël H et al. (2005) Rhone River flood deposits in Lake Le Bourget: A proxy for Holocene environmental changes in the NW Alps, France. Boreas 34(4): 404-416.

Chapron E, Bailly-Maitre M-C, Anselmetti FS et al. (2008) Impact of glacier fluctuations and high altitude mining activities on Late glacial-Holocene proglacial lacustrine sedimentation in the Grandes Rousses Massif (Western Alps, France). Collection EDYTEM, Cahiers de Paléoenvironnement 6: $39-50$.

Chapron E, Desmet M, De Putter T et al. (2002) Climatic variability in the northwestern Alps, France, as evidenced by 600 years of terrigenous sedimentation in Lake Le Bourget. The Holocene 12(2): 177-185.

Chapron E, Fain X, Magand O et al. (2007) Reconstructing recent environmental changes from proglacial lake sediments in the Western Alps (Lake Blanc Huez, 2543 m a.s.1., Grandes Rousses Massif, France). Palaeogeography Palaeoclimatology Palaeoecology 252: 586-600.

Cook ER, D'Arrigo RD and Briffa KR (1998) A reconstruction of the North Atlantic Oscillation using tree-ring chronologies from North America and Europe. The Holocene 8: 9-17.

Croudace IW, Rindby A and Rothwell RG (2006) ITRAX: Description and evaluation of a new x-ray core scanner. In: Rothwell RG (ed.) New Techniques in Sediment Core Analysis. London: Geological Society, pp. 51-63.

Curry M, McCartney S and Joyce TM (1998) Oceanic transport of subpolar climate signals to mid-depth subtropical waters. Nature 391: 575-577.

Dahl SO, Bakke J, Lie O et al. (2003) Reconstruction of former glacier equilibrium-line altitudes based on proglacial sites: An evaluation of approaches and selection of sites. Quaternary Science Reviews 22: 275-287.

Debret M, Chapron E, Desmet M et al. (2010) North western Alps Holocene paleohydrology recorded by flooding activity in Lake Le Bourget, France. Quaternary Science Reviews 29: 2185-2200.

Debret M, Sebag D, Crosta X et al. (2009) Evidence from wavelet analysis for a mid-Holocene transition in global climate forcing. Quaternary Science Reviews 28: 2675-2688

Delworth TL and Mann ME (2000) Observed and simulated multidecadal variability in the Northern Hemisphere. Climate Dynamics 16: $661-676$.

Deroin J-P and Condom T (2007) Retrait séculaire des glaciers locaux de montagne: Un exemple dans les Alpes occidentales françaises. Comptes Rendus Geoscience 339: 449-459.

Dickson RR, Lazier J, Meincke J et al. (1996) Long-term coordinated changes in the convective activity of the North Atlantic. Progress in Oceanography 38: 241-295.

Grinsted A, Moore JC and Jevrejeva S (2004) Application of the cross wavelet transform and wavelet coherence to geophysical time series. Nonlinear Processes in Geophysics 11: 561-566.

Guyard H, Chapron E, St-Onge G et al. (2007a) High-altitude varve records of abrupt environmental changes and mining activity over the last 4000 years in the Western French Alps (Lake Bramant, Grandes Rousses Massif). Quaternary Science Reviews 26: 2644-2660.

Guyard H, St-Onge G, Chapron E et al. (2007b) The AD 1881 earthquaketriggered a slump and late Holocene flood-induced turbidites from proglacial lake Bramant, Western French Alps. In: Lykousis V, Sakellariou D and Locat J (eds) Submarine Mass Movements and Their Consequences. Kluwer-Springer, pp. 279-286.

Guyard H, St-Onge G, Pienitz R et al. (2011) New insights into late Pleistocene glacial and postglacial history of northernmost Ungava (Canada) from Pingualuit Crater lake sediments. Quaternary Science Reviews 30: 3892-3907.

Higuchi K, Huang J and Shabbar A (1999) A wavelet characterization of the North Atlantic oscillation variation and its relationship to the North Atlantic sea surface temperature. International Journal of Climatology 19: 1119-1129. 
Holzhauser H, Magny M and Zumbühl HJ (2005) Glacier and lake level variations in west-central Europe over the last 3500 years. The Holocene 15(6): 789-801.

Hurrell JW (1995) Decadal trends in the North Atlantic Oscillation: Regional temperatures and Precipitation. Science 269: 676-679.

Hurrell JW and Van Loon H (1997) Decadal variations in climate associated with the North Atlantic Oscillation. Climatic Change 36: 301-326.

Huss M, Hock R, Bauder A et al. (2010) 100-year mass changes in the Swiss Alps linked to the Atlantic Multidecadal Oscillation. Geophysical Research Letters 37: L10501, 22(2): 235-247.

Imhof P, Nesje A and Nussbaumer SU (2012) Climate and glacier fluctuations at Jostedalsbreen and Folgefonna, southwestern Norway and in the western Alps from the 'Little Ice Age' until the present: The influence of the North Atlantic Oscillation. The Holocene 22(2): 235-247.

Keenlyside NS, Latif M, Jungclaus J et al. (2008) Advancing decadal-scale climate prediction in the North Atlantic sector. Nature 453: 84-88.

Kerr RA (2000) A North Atlantic climate pacemaker for the centuries. Science 288: $1984-1986$

Knight JR, Allan RJ, Folland CK et al. (2005) A signature of persistent natural thermohaline circulation cycles in observed climate. Geophysical Research Letters 32: L20708, DOI 10.1029/2005GL024233.

Knight JR, Folland CK and Scaife AA (2006) Climate impacts of the Atlantic Multidecadal Oscillation. Geophysical Research Letters 33: L17706, DOI 10.1029/2006GL026242.

Knudsen MF, Seidenkrantz M, Jacobsen BH et al. (2011) Tracking the Atlantic Multidecadal Oscillation through the last 8,000 years. Nature Communication 2: DOI 10.1038/ncomms1186.

Kushnir Y (1994) Interdecadal variations in North Atlantic sea surface temperature and associated atmospheric conditions. Journal of Climatology 7: 141-157.

Luterbacher J, Schmutz C, Gyalistras D et al. (1999) Reconstruction of monthly NAO and EU indices back to AD 1675. Geophysical Research Letters 26(17): 2745-2748.

Luterbacher J, Xoplaki E, Dietrich D et al. (2002) Extending North Atlantic Oscillation reconstructions back to 1500. Atmospheric Science Letters 2(1-4): 114-124.

Magny M (2004) Holocene climate variability as reflected by mid-European lake-level fluctuations and its probable impact on prehistoric human settlements. Quaternary International 113: 65-79.

Marzeion B and Nesje A (2012) Spatial patterns of North Atlantic Oscillation influence on mass balance variability of European glaciers. The Cryosphere 6: 661-673.

Neemann A and Niessen F (1994) Holocene glacial activity and climatic variations in the Swiss Alps: Reconstructing a continuous record from proglacial lake sediments. The Holocene 4: 259-268.

Nesje A (2009) Latest Pleistocene and Holocene alpine glacier fluctuations in Scandinavia. Quaternary Science Reviews 28: 2119-2136.

Nesje A and Dahl SO (2003) The 'Little Ice Age' - Only temperature? The Holocene 13(1): 139-145.

Nesje A, Dahl SO, Thun T et al. (2008) The 'Little Ice Age' glacial expansion in western Scandinavia: Summer temperature or winter precipitation? Climate Dynamics 30(7-8): 789-801

Nesje A, Lie Ø and Dahl SO (2000) Is the North Atlantic Oscillation reflected in Scandinavian glacier mass balance records? Journal of Quaternary Science 15(6): 587-601.

Nussbaumer SU, Zumbühl HJ and Steiner D (2007) Fluctuations of the Mer de Glace (Mont Blanc area, France) AD 1500-2050: An interdisciplinary approach using new historical data and neural network simulations. Zeitschrift für Gletscherkunde und Glazialgeologie 40: $1-183$

Pauling A, Luterbacher J, Casty C et al. (2006) 500 years of gridded highresolution precipitation reconstructions over Europe and the connection to large-scale circulation. Climate Dynamics 26: 387-405.

Reichert BK, Bengtsson L and Oerlemans J (2001) Midlatitude forcing mechanisms for glacier mass balance investigated using general circulation models. Journal of Climate 14: 3767-3784.

Roberts N, Moreno A, Valero-Garcés BL et al. (2012) Palaeolimnological evidence for an east-west see-saw in the Mediterranean since AD 900. Global and Planetary Change 84-85: 23-34.

Rodwell MJ, Rodwell DP and Folland CK (1999) Oceanic forcing of the wintertime North Atlantic Oscillation and European climate. Nature 398: 320-323.

Rogers JC (1984) The association between the North Atlantic Oscillation and the Southern Oscillation in the Northern Hemisphere. Monthly Weather Review 112: 1999-2015.

Scherrer SC, Appenzeller C and Laternser M (2004) Trends in Swiss Alpine snow days: The role of local- and large-scale climate variability. Geophysical Research Letters 31: L13215, DOI 10.1029/2004GL020255.

Schlesinger ME and Ramankutty N (1994) An oscillation in the global climate system of period 65-70 years. Nature 367: 723-726.

Selten FM, Haarsma RJ and Opsteegh JD (1999) On the mechanism of North Atlantic Decadal variability. Journal of Climate 12: 1956-1973.

Shaw E-M, Ahmad M and Cailleux A (1958) Le cône torrentiel du Lac Tournant. Revue de Géographie Alpine 46(3): 455-462.

Six D, Reynaud L and Letréguilly A (2001) Bilans de masse des glaciers alpins et scandinaves, leurs relations avec l'oscillation du climat de l'Atlantique nord. Earth and Planetary Sciences 333: 693-698.

Steiner D, Pauling A, Nussbaumer SU et al. (2008) Sensitivity of European glaciers to precipitation and temperature - Two case studies. Climatic Change 90(4): 413-441.

Stuiver M, Grootes PM and Braziunas TF (1995) The GISP2 $\delta^{18} \mathrm{O}$ record of the past 16500 years and the role of the sun, ocean and volcanoes. Quaternary Research 44: 341-354.

Sutton RT and Hodson DLR (2005) Atlantic Ocean forcing of North American and European summer climate. Science 309(5731): 115-118.

Torrence C and Compo GP (1998) A practical guide to wavelet analysis. Bulletin of the American Meteorological Society 79: 61-78.

Vincent C (2002) Influence of climate change over the 20th century on four French glacier mass balances. Journal of Geophysical Research 107(D19): 4375, DOI 10.1029/2001JD000832.

Vincent C, Le Meur E and Six D (2005) Solving the paradox of the end of the Little Ice Age in the Alps. Geophysical Research Letters 32: L09706, DOI 10.1029/2005GL022552.

Wanner H, Rickli R, Salvisberg E et al. (1997) Global climate change and variability and its influence on Alpine climate - Concepts and observations. Theoretical and Applied Climatology 58: 221-243.

Wanner H, Solomina O, Grosjean M et al. (2011) Structure and origin of Holocene cold events. Quaternary Science Reviews 30: 3109-3123.

Witt A and Schumann AY (2005) Holocene climate variability on millennial scales recorded in Greenland ice cores. Nonlinear Processes in Geophysics 12: $345-352$

Zemp M (2006) Glaciers and climate change - Spatio-temporal analysis of fluctuations in the European Alps after 1850. Physische Geographie Glaziologie und Geomorphodynamik 49: 1-201.

Zhu X and Jungklaus J (2008) Interdecadal variability of the meridional overturning circulation as an ocean internal mode. Climate Dynamic DOI $10.1007 / \mathrm{s} 00382-008-0383-9$. 